\title{
Three Strigeid cercariae from Littorina littorea snail, Qarun Lake, Fayoum, Egypt
}

\author{
Fayez A. Bakry ${ }^{1}$, Marwa Th. Atwa² and Marwa M. Attia ${ }^{3}$
}

1. Department of Medical Malacology Theodor Bilharz Research Institute, Giza, Egypt; 2. Department of Zoology, Faculty of Science, Fayoum University, Fayoum Governorate, Egypt; 3. Department of Parasitology, Faculty of Veterinary Medicine, Cairo University, Giza, Egypt.

Corresponding author: Fayez A. Bakry, e-mail: Fayezbakery@yahoo.com

Co-authors: MTA: fab201355@gmail.com, MMA: Kab442016@gmail.com

Received: 22-11-2017, Accepted: 09-02-2018, Published online: 14-03-2018

doi: 10.14202/vetworld.2018.310-315 How to cite this article: Bakry FA, Atwa MT, Attia MM (2018) Three Strigeid cercariae from Littorina littorea snail, Qarun Lake, Fayoum, Egypt, Veterinary World, 11(3): 310-315.

\begin{abstract}
Aim: The present study aims to focus on the role of common marine snails (Littorina littorea) as a vector for some trematode parasites.

Materials and Methods: A total of 327 marine water L. littorea snails were collected during the summer of 2016 from a Qarun lake in the EL-Fayoum Governorate, Egypt. The snails were investigated for infection by trematode parthenitae through induction of cercarial shedding by exposure to light and crushing the snails. The species were stored in Search Laboratory of Zoology Department, Faculty of Science, Fayoum University.

Results: Three species of Strigeid littorina cercaria were identified from the infected snails. They are described here and they identified in relation to close-up morphological features and linked to its snail hosts. They give the following names: Cercaria strigeid littorina type 1,C. strigeid littorina type 2, and C. strigeid littorina type 3. The incidence of infection by these cercariae was $33 \%, 25.7 \%$, and $2.4 \%$, respectively.
\end{abstract}

Conclusion: This study is clarifying the importance of this marine snail as intermediate hosts for new trematode species.

Keywords: Littorina littorea, Qarun Lake, Strigeid Cercaria.

\section{Introduction}

Lake Qarun is the third largest lake in Egypt and the second most famous one after Lake Nasser in the Southern part of Egypt. It lies $45 \mathrm{~m}$ below sea level and occupies the lowest, northern section of the Fayoum depression. It is a marine lake containing different types of fish, snails, and seabirds along the year. The study of animal parasites in the Lake Qarun region began with the report of Al-Bassel [1] and Abdel-Ghaffar et al. [2,3].

Littorina littorea possesses an operculum that is used to close off the shell aperture on disturbance, analogous to the hiding responses and withdrawal responses seen in other animals [4]. Parasitic infection can alter the host behavior in ways that might be adapted for the parasite, with parasite-induced behavioral changes apparent at the sample mean level [5]. Parasites might impact behavior at the level of animal personalities (Hammond-Tooke et al. [6] and Poulin [7]) as well as at the sample mean. However, only a few studies $[6,8,9]$ have investigated this possibility empirically.

Copyright: Bakry, et al. Open Access. This article is distributed under the terms of the Creative Commons Attribution 4.0 International License (http://creativecommons.org/licenses/by/4.0/), which permits unrestricted use, distribution, and reproduction in any medium, provided you give appropriate credit to the original author(s) and the source, provide a link to the Creative Commons license, and indicate if changes were made. The Creative Commons Public Domain Dedication waiver (http://creativecommons.org/ publicdomain/zero/1.0/) applies to the data made available in this article, unless otherwise stated.
Several authors still interested in studying the disease and its vectors in and around the lake. According to the water movement, large numbers of snails usually present more superficial around the lake boundaries and even on the ground. These snails considered an edible food for most of seabirds that fly around the lake and the snails are rather ingested by birds accidentally with stones. Inspection of these snails proved that they contain variable trematode parthenita that usually infects these birds as well as fish [10-12].

Huxham et al. [10] and Galaktionov and Dobrovolskij [12] revealed that $L$. littorea snail is one of these abundant snail species available to be picked up by seabirds as food. It is a marine gastropod mollusk(Phylum: Mollusca, Class: Gastropoda, Order: Prosobranchia, Suborder: Neotaenioglossa, Family: Littorinidae, Genus: Littorina, Species L. littorea). It has gills and an operculum. It is $10-12 \mathrm{~mm}$ in maximum width and about $16-38 \mathrm{~mm}$ in length, with broadly oval shell. The snail is mainly found on rocky shores in the higher and middle internal zone. It sometimes lives in small tide pools. It may also be found in muddy habitats such as estuaries and can reach depths of $180 \mathrm{ft}$.

The parasite fauna infecting L. littorea has been investigated previously by Seaman and Briffa [13] and Pechenik et a1. [14]. They were diagnosed up to five species of trematodes (Cryptocotyle lingua, Cercaria parvicaudata, Renicola roscovita, Microphallus pygmaeus, and Microphallus similes) in L. littorea. This 
snail is the first intermediate host (IMH) to the larval stages of Cryptocotyle lingua and C. parvicaudata. The snails ingest eggs of both parasites deposited in the feces of gulls (Larus spp.). Cercariae are released from infected snails and infect the second IMH, as metacercariae encyst on fish skin while C. parvicaudata infects bivalve mollusk $[14,15]$.

Role of snails as IMH for new parasites still needs more investigations aiming to determine the epidemiology of new parasites and determine the best way of controlling them $[16,17]$.

With respect to the previous experiences of the authors in the field of trematode parthenitae in this locality, The aim of the current study was to spotlight on the role of the common marine snails (L. littorea) as a vector for some trematode parasites that can be transmitted from them to other hosts.

This research focused on the prevalence of cercariae in the snail. We recommended that further researches to be done about biological manipulation of the parasites as no studies about this issue in this locality reported previously and so little information is available about this.

We focused in this article on new species, but we found other species and we cannot find schistosomiasis during the period of the study.

\section{Materials and Methods}

Ethical approval

The Institutional Animal Ethics Committee and local laws and regulations were considered in applying our experiment.

\section{Study area}

The present study was done on Qarun marine water lake at the North West region of El-Fayoum Governorate. The Governorate is an oasis in the western desert $100 \mathrm{~km}$ southwest of Cairo. It lies between Latitude of $29^{\circ} 4^{\prime} 17^{\prime \prime} \mathrm{N}$ and Longitude of $30^{\circ} 7^{\prime} 12^{\prime \prime} \mathrm{E}$.

\section{Collected samples}

L. littorea snails were collected manually according to the method described by Mandahi-Barth [18] using suitable long-handled net. The snails were separated from the associated submerged vegetation by several agitations in clean lake water. Collected snails were picked up manually and maintained in the laboratory during investigation in the same water in clean plastic aquaria supplied by its some vegetation. The snails were identified according to McQuaid [19].

\section{Inspection of snails}

All collected snails were examined for trematode infection by light exposure and crushing techniques [20] as the following: The snails were investigated for the presence of infection by the exposure technique as 3-5 selected snails (10 replicates) which were placed in a Petri dishes half filled with clear filtered natural lake water. They exposed to a direct light using 100 watts electrical lambs for 1-2 $\mathrm{h}$ under observation. The normally shed cercariae were picked up directly and fixed for identification as well as for measurements. An alternative technique was used by crushing representative samples from the collected snails directly in suitable Petri dishes with a few amount of water under a dissecting microscope, where available parthenitae were recorded by El-Bahy et al. [20].

\section{Examination of the obtained stages}

Fresh obtained living Cercaria and sporocysts were stained by supravital stain using dilute solutions vital dyes as Neutral red and Nile blue sulfate according to Cable [21]. Moreover, the dead relaxed specimens were fixed and stained for the preparation of permanent mounted using the technique described by Prichard and Kruse [22]. Detected trematode parthenita was identified according to Diab [23], then recorded for each snail species separately.

\section{Detailed inspection and measuring of the stages}

During observation of shed cercariae, all biological characters were recorded including time of shedding, movement, and behavior of the cercariae from time of shedding till death or encystment. This was done on samples of directly shed cercariae after they transferred to a suitable Petri dish in enough amount of water under laboratory conditions $\left(20-25^{\circ} \mathrm{C}\right)$.

For measuring the cercariae, they were fixed according to Cort and Brackett [24], where a small quantity of water containing the cercariae was placed in a container and then an equal volume of $10 \%$ formalin heated to boiling was added. A number of 25 well-relaxed moist-heat killed stages were measured.

All measurements were taken with the aid of eyepiece micrometer. Measurements were given in microns and both minimum and maximum figures were recorded in the description, with the average being given in parentheses.

Sporocysts were studied alive under the microscope. Longevity and other living habits of these larvae were also studied. Measurements were made from specimens fixed in 5\% formalin and stained with acetic acid alum carmine.

\section{Results}

During the summer season of 2016, a number of 327 L. littorea snails (Figure-1a) were collected and inspected for diagnosing the rate of infection by different trematode parthenitae. As described in Table-1, three cercariae and their parthenitae were diagnosed in the inspected snail. They are characterized as follows:

\section{Conditions of infection}

State either a snail was infected with mixed infection by more than one type of Cercaria (as type 1 and type 2 which were found together in the same snail) or infected with a single infection with only one type of Cercaria (as type 3 which was found singular in the snail). 
Table-1: Distribution of the target Cercariae in the examined L. littorea snail.

\begin{tabular}{lccc}
\hline Cercaria type & No. examined & No. infected & \% and conditions of infection \\
\hline $\begin{array}{l}\text { Cercaria strigeid } \\
\text { Littorina type 1 }\end{array}$ Cercaria strigeid & 327 & 109 & $33 \%-$ mixed inf. \\
$\begin{array}{l}\text { Littorina type 2 } \\
\text { Cercaria strigeid }\end{array}$ & 327 & 84 & $25.7 \%-$ mixed \\
Littorina type 3 & 327 & 8 & $25.7 \%-$ mixed \\
\hline
\end{tabular}

$\%=$ The percentage of infection (The number of infected snails related to the total number of examined snails)

\section{$1^{\text {st }}$ identified Cercaria and its sporocyst}

\section{Cercaria strigeid littorina type 1 (Figure-1b and c)}

This Cercaria is a type of Strigeid cercariae, and it was diagnosed in $33 \%$ of the inspected snails. It is characterized by the body of the same width but considerably shorter than tail stem; furca is almost as long as the tail stem; The body measured $151-200 \mu$ in length (mean of $175.5 \mu$ ) and 50-77 $\mu$ (mean 63.5 $\mu$ ) in width. The distance from middle of ventral sucker to the posterior end of body was about 55-76 $\mu$ (mean $65.5 \mu$ ). The tail stem was about $290-330 \mu$ (mean is $310 \mu$ ) length. Furca is long and was about $300-354 \mu$ (mean $327 \mu$ ) in length.

The oral and ventral suckers were prominent and were approximately of the same diameter that measured 28-36 $\mu($ mean=32 $\mu)$ length and about 27-34 $\mu$ (mean of $30.5 \mu$ ) width. The prepharynx was extremely short. The pharynx was short. Esophagus was moderately long and divided into two simple intestinal ceca extending to the level of posterior margin of the ventral sucker. One row of small spines encircles ventral sucker. Penetration glands, coarsely granular, eight in number, four are lying in front of and four are behind ventral sucker. Their ducts ran in sinuous course and opened at the tip of the body around the oral sucker.

Cercaria advanced inside Sporosest elongated (Figure -1c). The young sporocysts were narrow and tubular with a size of $0.225-0.391 \mathrm{~mm}(0.308 \mathrm{~mm})$ and the length of $0.135-0.145 \mathrm{~mm}(0.14 \mathrm{~mm})$ width.

Some sporocysts were as large as $3.11 \mathrm{~mm}$ length. In some cases, the width of the sporocyst was very uniform along its entire length (Figure-1b), but others had swollen portions connected by narrower regions (Figure-1b). The ends of sporocysts may be pointed or rounded, and no direct correlation was found between the size of sporocyst and the presence of Cercaria within the sporocyst.

When cercariae hang freely in water, tail stem was bent sharply to side and there was a marked constriction in posterior body.

Following up the previous description of similar cercariae, this type could be identified as a species from Strigeid cercariae, and concerning its snail $\mathrm{IMH}$, the author suggests identifying this species as C. strigeid littorina type 1 (Figure-1b and c).

\section{The $2^{\text {nd }}$ identified Cercaria and its sporocyst}

\section{C. strigeid littorina type 2 (Figure-1d and e)}

It was another type of large Strigeid Cercaria. It infected $25.7 \%$ of the examined snails. It was usually

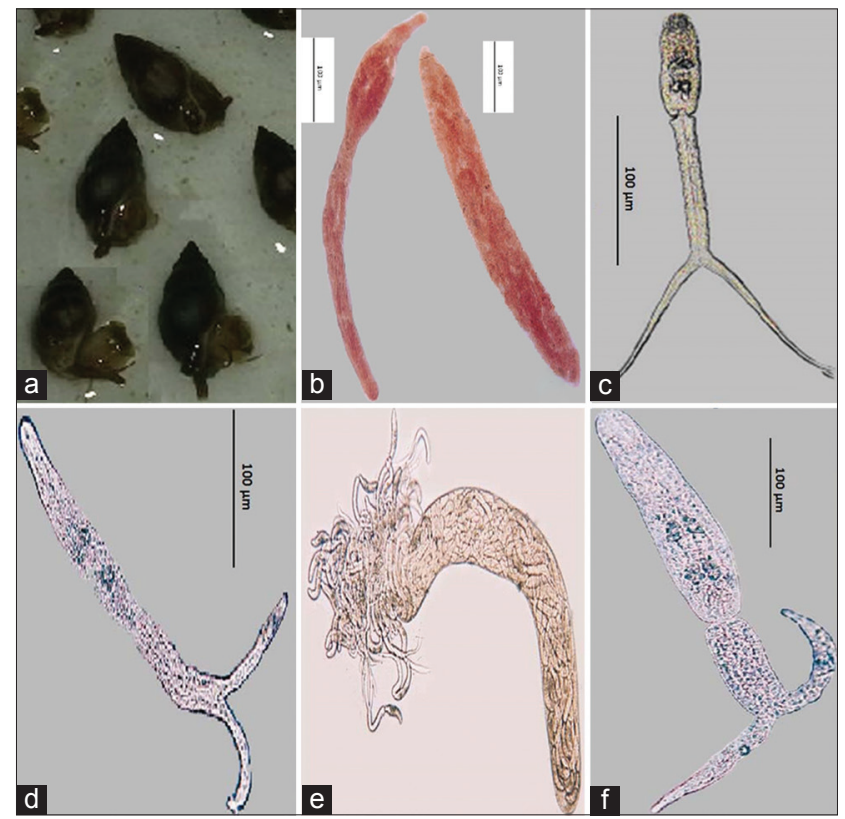

Figure-1: (a) Littorina littorea active snail, (b) Sporocyst contain Cercaria strigeid littorina type 1, (c) C. strigeid littorina type 1, (d) C. strigeid littorina type 2, (e) Sporocyst contain C. strigeid littorina type 2, (f) C. strigeid littorina type 3.

present in mixed infection with the first type. Its body was $255-290 \mu(272.5 \mu)$ length and $44-52 \mu(48.0 \mu)$ width. Tail stem was slightly shorter than body length, which measured 205-275 $\mu$ (mean of $240 \mu$ ) length and $41-51 \mu$ (mean $46 \mu)$ width.

The length of the furcal was $189-220 \mu(204.5 \mu)$. The oral sucker was wide in living specimens, elongation when fixed and slightly larger than a ventral sucker, measuring 44-51 $\mu(47.5 \mu)$ in the and 25-28 $\mu$ $(26.5 \mu)$ in width,while ventral sucker measured 32-37 $\mu(34.5 \mu)$ in length and 18-23 $\mu(20.5 \mu)$ in width. Pharynx was small, esophagus was narrow, and intestinal cake was extended to ventral sucker. Penetration glands were small, very inconspicuous and eight in number, four are lying in front of ventral sucker and the others are behind the ventral sucker. Gland ducts ran forward and opened around the oral sucker.

The body surface was armed with spines, and most of them had 12 transverse rows which had a weakly scalloped appearance to the body surface during body contraction. Ventral sucker had two to three rows of spines.

The tail stem surface, particularly, the anterior surface was covered with small spines. The digestive 
system was well developed. The prepharynx was short leads to the short pharynx, while the length of the esophagus was 6-8 times the length of the pharynx. The esophagus ended at a bifurcation located a short distance anterior to the ventral sucker, and from this point, the ceca extended laterally and posteriorly to the excretory bladder.

The examination on living material showed that a birth pore, through which the cercariae emerged, was present at one end of the sporocyst (Figure-1e).

Swimming activity was not affected by exposure to different light intensities. Swimming activity was in the form of very rapid whipping of tail back and forth followed by a period of inactivity during which the Cercaria was suspended, body downward, in the water.

Following up the previous description of similar cercariae, this type could be identified as a species from Strigeid Cercaria and concerning its snail IMH. The author suggests identifying this species as C. strigeid littorina type 2 (Figure-1c).

\section{The $3^{\text {rd }}$ identified Cercaria}

\section{C. strigeid littorina type 3 (Figure-1f)}

It is another type of Strigeid Cercaria. It was diagnosed in just $2.4 \%$ of the inspected snail. It was present in single infection not associated with other types. Its body was $230-265 \mu$ length (mean, $247.5 \mu$ ) and 55-67 $\mu$ width (mean $61.0 \mu$ ).

Tail stem was clearly shorter than body length measured 120-134 $\mu$ length (mean, $127.0 \mu$ ) and 45-51 $\mu$ width (mean, $48.0 \mu$ ), furca elongate, contractile measured $118-130 \mu$ (mean, $124.0 \mu$ ). Oral sucker was elongate and slightly larger than ventral sucker measured 48-53 $\mu$ (mean, $50.0 \mu$ ) length and 31-37 $\mu$ (mean, $34.0 \mu$ ) width, while ventral sucker measured 41-47 $\mu(44.0 \mu)$ length and 25-32 $\mu$ (mean, $28.5 \mu$ ) width. Pharynx was slightly larger, and esophagus was short and leads to two intestinal ceca. Penetration glands were small and twelve in number, six lying in front of and six are behind the ventral sucker. Ventral sucker had several irregular rows of flattened spines of various sizes. Excretory system was typical of strigeids. Three flame cells were on each anterior collecting tubule. Five flame cells were found on each posterior collecting tubule. No caudal bodies were present in tail stem.

The emergence and activity of this species were not studied adequately because the cercariae emerged in small number. The cercariae emerged during most of the day, but shedding occurred mainly in the afternoon. After resting for varying periods of time, they swam upward and vertically. When they stopped, the furca was held at right angles to the tail stem. Then, the furca gradually assumed a position at right angles to each other (Figure-1f).

Following up the previous description of similar cercariae, this type could be identified as a species from Strigeid Cercaria, and concerning its snail
IMH, the authors suggest identifying this species as C. strigeid littorina type 3 (Figure-1f).

\section{Discussion}

The snail L. littorea is a marine water snail, inhabits the Lake Qarun, and usually lives above the mean high tide line. The snails are occasionally present in very large numbers as they are easy to be collected. Collection and examination of 327 Littorea sp., $10-14 \mathrm{~mm}$ length during the summer of 2016 , revealed infection by sporocysts and cercariae in 33\% of the snails with $C$. streiged littorina type 1 .

This Cercaria has an excretory system with clear commissure that developed and located at the posterior end of the body. Excretory duct runs in the middle of tail stem and along the furca to open on their tips. Tail stem has a limited number of large, uniform caudal bodies.

The recorded C. strigeid littorina type 1 in the present study was characterized by having a limited number of large, rather uniform caudal bodies in the tail stem as in Cercaria emarginatae Cort [25] and Cercaria dohema Cort and Brackett [24], but this Cercaria is distinguished from them by its characteristic form and number of its penetration gland and also unusually long furcae.

From numerous previously described species of Strigeid cercariae, two species, Cercaria macradena and C. microdena Cort and Bracket [26], obtained from Douglas Lake region from Stagnicola palustris snails, are similar morphologically to our Cercaria that identified as $C$. strigeid littorina type 2 as it having penetration gland in front and behind the ventral sucker, excretory pattern, and body spinabion, but differ significantly in size, proportions, and the number and size of penetration glands.

The obtained Strigeid littorina cercaria type 2 in the present study was similar to cercaria higginsi [27] which obtained from lymnaeid snails collected in northern Michigan in morphology, size, proportions, where the body and tail stem are very approximately equal in size, and the hanging in the water but differ significantly in having eight penetration glands in front and behind the ventral sucker. While $C$. higginsi has six small penetration gland posterior to ventral sucker and also the tail stem has no caudal bodies.

A single snail was infected with both $C$. strigeid littorina type 1 and C. strigeid littorina type 2. This result does not provide evidence of competitive trematode interactions within L. littoria [28], but the typical cooccurrence of two parasites in any snail would be rare [29]. The $3^{\text {rd }}$ species that give the name of C. strigeid littorina type 3 has all characteristic features of the cercariae belonging to the family Strigeidae. This Cercaria is similar to Cercaria sincera which described by Olivier [27] in the dimensions of tail stem and furca and in having the same structure of the excretory system. However, C. strigeid littorina type 3 was characterized chiefly by its penetration 
glands, it has six lying in front and six behind the ventral sucker, while $C$. sincera has two pairs of small penetration glands lateral or anterior to the ventral sucker. The present Cercaria distinguished also by its unusual short tail stem if compared with body length where it is smaller $1 \frac{1}{2}$ times the length of the body.

Among 327 specimens of $L$. littorea snails collected on May 2016 from Lake Qarun, eight snails only $(2.4 \%)$ were infected with this species of Cercaria where the Cercaria was found in single infection, unlike the two previous species (C. strigeid littorina type 1 and $C$. strigeid littorina type 2 ) where they were found in double infect. The predominance of infections by one parasite (C. strigeid littorina type 3 ) could be suggest that $C$. strigeid littorina type 3 determines the outcome of interactions by arriving first and determine other infections [30] or that C. strigeid littorina type 3 is the competitive dominant regardless of which parasite infects the host first [28]. Possibilities also include immunological responses or cellular tissue reactions in the snail host induced by concurrent heterospecific infection, toxic chemical compounds released by the larvae, or competition for nutrients or oxygen. This possibility appears to enhance super infection by only one parasite [31,32].

We depend on the identification to the family level and we gave these names for cercariae as they are new species.

\section{Conclusion}

This study increases the importance of L. littoria snails as a source of infection of new parasites. Moreover, further epidemiological studies continued now to identify the adult worms of these three species of strigeid Cercaria to evaluate its effects on the probable final hosts if it is fish or water birds.

\section{Authors' Contributions}

FAB and MTA were in charge of designing the study and writing the manuscript. The samples were taken by MTA and MMA. The supervision of the laboratory work performed by FAB and MTA. All authors have read and approved the final manuscript.

\section{Acknowledgments}

The authors are kindly thankful to Faculty of Science, Fayoum University, Egypt, for covering all the expenses of the experiment needed to conduct the work. This research received no specific grant or fund from any funding organizations.

\section{Competing Interests} interests.

The authors declare that they have no competing

\section{References}

1. Al-Bassel, D.H.M. (1994) Lecithobotrys imami, a new trematod from mullet of lake Qarun in Egypt. Beni Suef Vet. Med. Res., 4: 304-314.

2. Abdel-Ghaffar, F., Ibrahim, E.A., Bashtar, A. and Ali, M.A.
(1998) Myxosporidia infecting saline and freshwater fishes of Qarun and Wadi El-raiyan lakes, Egypt. J. Egypt. Ger. Sco. Zool., 26: 209-229.

3. Abdel-Ghaffar, F., Amira, K.A., Bakry, F.A., Rabei, I. and Ibrahim, A. (2016) The impact of three herbicides on biological and histological aspects of Biomphalaria alexandrina, intermediate host of Schistosoma mansoni. Malacologia, 59: $197-210$.

4. Briffa, M. (2013) Plastic proteans: Reduced predictability in the face of predation risk in hermit crabs. Biol. Lett., 9: 592.

5. Stunkard, H.W. (1950) Further observation on Cercaria parvicaudata stunkard and shaw 1931. Biol. Bull., 99(1): 136-142.

6. Hammond-Tooke, C., Nakagawa, S., and Poulin, R. (2012) Parasitism and behavioural syndromes in the fish Gobiomorphus cotidianus. Behaviour, 149: 601-622.

7. Poulin, R. (2013) Parasite manipulation of host personality and behavioural syndromes. J. Exp. Biol., 216: 18-26.

8. Pruitt, J.N., Stachowicz, J.J. and Sih, A. (2012) Behavioral types of predator and prey jointly determine prey survival: Potential implications for the maintenance of within-behavioral variation. Am. Nat., 179: 217-227.

9. Kekäläinen, J., Lai, Y. and Vainikka, A. (2014) Do brain parasites alter host personality? Experimental study in minnows. Behav. Ecol. Sociobiol., 68: 197-204.

10. Huxhama, M., RafIae, I.D. and Pikeb, A. (1993) The influence of Cryptocotyle lingua (Digenea: Platyhelminthes) infections on the survival and fecundity of Littorina littorea (Gastropoda: Prosobranchia); An ecological approach. J. Exp. Mar. Biol. Ecol., 168: 223-238.

11. Di Rienzo, N., Niemelä, P.T., Hedrick, A.V. and Kortet, R. (2016) Adult bacterial exposure increases behavioral variation and drives higher repeatability in field crickets. Behav. Ecol. Sociobiol., 70: 1941-1947.

12. Galaktionov, K.V. and Dobrovolskij, A.A. (2003) The Biology and Evolution of Trematodes: An Essay on the Biolgy, Morphologym Life Cycles, Transmissions, and Evolution of Digenetic Trematodes. Springer, The Netherlands. p602.

13. Seaman, B. and Briffa, M. (2015) Parasites and personality in periwinkles (Littorina littorea): Infection status is associated with mean-level boldness but not repeatability. Behav. Proc., 115: 132-4.

14. Pechenik, J.A., Fried, D. and Simpkins, H.L. (2001) Crepidula fornicate is not the first intermediate host for trematodes: Who is? J. Exp. Mar. Biol. Ecol., 261: 211-224.

15. Bakry, F.A. and Ismail, S.M. (2017) Impact of plant extracts on parasitological and histological parameters of albino mice infected with Schistosoma mansoni. J. Biomater., 1: $10-18$

16. El Deebm, N. and Bakry, F.A. (2017) Antischistosomal and immuno-biochemical effect of miltefosine and plant extracton infected albino mice with Schistosoma mansoni. Int. J. Biol. Pharm. Allied Sci., 6: 676-690.

17. Bakrym, F.A., El-Garhy, M., Abd El-Atti, M. and Atwa, M.T. (2017) Effects of the extracts of Euphorbia pulcherima and Atriplex nummularia on the infectivity of Schistosoma haematobium to Bulinus truncatus Snails. Adv. Biomech., 1: 34-41.

18. Mandahl-Barth, G. (1962) Key to the identification of east and central African freshwater snails of medical and veterinary importance. Bull. Wld. Health Org., 27: 135-150.

19. McQuaid, C.D. (1996) Biology of the gastropod family Littorinidae. II. Role in the ecology of intertidal and shallow marine ecosystem. Oceanogr. Mar. Biol., 34: 19.

20. El-Bahy, M.M., Mahgoub, A.M. and Taher, E.E. (2014) Contributions on human fascioliasis and its snail intermediate host in Nile Delta. Egypt. J. Basic Appl. Sci., 3: 172-179.

21. Cable, R.M. (1977) An Illustrated Laboratory Manual of Parasitology. $5^{\text {th }}$ ed. Burgess Publishing Company, Minneapolis, Minnesota, U.S.A. p237.

22. Prichard, M.H. and Kruse, G.O.W. (1982) The Collection 
and Preservation of Animal Parasites. University of Nebraska, Lincoln and London.

23. Diab, M.R. (1993) Biological Studies on Trematode Larvae and Fresh Water Snails. M. V.Sc. (Thesis) Faculty of Veterinary Medicine. Alexandria University.

24. Cort, W.W. and Brackett, S. (1937) Two new species of striged cercariae from the Douglas lake Region, Michigan. J. Parasitol., 23: 265-280.

25. Cort, W.W. (1917) Homologies of the excretory system of the forked-tailed cercariae. J. Parasitol., 4: 49-57.

26. Cort, W.W. and Brackett, S. (1938) Two new species of strigeid cercariae in stagnicol apalustriselodes (say) from the dougles lake Region, Michigan. Trans. Am. Microsc. Soc. 57: 274-281.

27. Olivier, L. (1941) Three new species of strigeid cercariae from the dougles lake region, michigan. Trans. Am. Microsc.
Soc., 60: 45-52.

28. Lambert, W.J., Corliss, E., Sha, J. and Smalls, J. (2012) Trematode infections in Littorina littorea on the new hampshire coast northeastern. Naturalist, 19: 461-474.

29. Curtis, L.A. (2002) Ecology of larval trematodes in three marine snails. Parasitology, 124: S43-S56.

30. Souse, W.P. (1992) Interspecific interactions among larval trematodeparasites of fresh water and marine snails. $\mathrm{Am}$. Zool., 32: 583-592.

31. Lie, K.J. (1966) Antagonistic interactions between Schistosoma mansoni sporocysts and echinostoma rediae in snail austrolorbisglabratus. Nature, 211: 1213-1215.

32. Lie, K.J. (1969) A possible biological control of schistosomiasis and other trematodes in snails. In: Harinasuta, C., editor. Proceedings $4^{\text {th }}$ Southeast Asian Seminar on Parasitol. Tropic.Medic. SEAMEC, Bangkok. p131-141.

$* * * * * * * *$ 